Türkiye Tarımsal Araştırmalar Dergisi
http://dergi.siirt.edu.tr/index.php/ziraat

\title{
Kireçleme Materyali Olarak Kullanılan Şeker Sanayi Atı̆̆ı Şlamın Çay Bitkisinin Verim, Kalite ve Toprak Özelliklerine Etkisi
}

\author{
Gülen ÖZYAZICI ${ }^{1 *}$, Osman ÖZDEMİR ${ }^{1}$, Safiye Pınar ÖZER ${ }^{2}$, Zühal KALCIOĞLU ${ }^{2}$ \\ ${ }^{I}$ Karadeniz Tarımsal Araştırma Enstitüsü Müdürlüğ̈̈, Samsun, TÜRKIYYE \\ ${ }^{2}$ Atatürk Çay ve Bahçe Kültürleri Araştırma Enstitüsü Müdürlüğü, Rize, TÜRKIYYE
}

\begin{abstract}
Geliş Tarihi/Received: 28.01 .2014
Kabul Tarihi/Accepted: 25.02 .2014

*Sorumlu Yazar/Correspondence: gulenozyazici@hotmail.com

Özet: Bu çalışma şeker sanayi atığı şlamın asit topraklarda çay sahalarında tarım kireci yerine ne kadar kullanılacağının ve toprağın kimyasal yapısında meydana getirebileceği değişikliklerin belirlenmesi amacıyla yürütülmüştür. Araştırma, Rize Merkez ve İyidere ilçesinde olmak üzere 3 lokasyonda 2009-2011 yıllarında yürütülmüştür. Tarla denemeleri tesadüf bloklarında 3 tekrarlamalı olarak kurulmuştur. Kireç ve şlam uygulamaları, yaş çay yaprağ $(\mathrm{p}<0.01 ; \mathrm{p}<0.05)$ artırmış olup en yüksek verim, kireç ihtiyacının tamamı kadar şlam uygulamasından elde edilmiştir. Çaykur Araştırma Enstitüsü lokasyonunda yaş çay yapră̆ı verimini şlam uygulaması \% 22.9, İyidere-1 lokasyonunda $\%$ 13.4, İyidere-2 lokasyonunda ise \% 18.6 oranında artırmıştır. Araştırmada hasat sonrasında toprak örnekleri alınarak analiz edilmiştir. Çaykur Araştırma Enstitüsü lokasyonunda toprak $\mathrm{pH}$ 'sı ile değișebilir $\mathrm{Ca}\left(\mathrm{r}=0.53^{*}\right)$ arasında pozitif, çinko $\left(\mathrm{r}=-0.55^{*}\right)$ ile negatif önemli ilişki belirlenmiştir. İyidere-1 lokasyonunda toprak $\mathrm{pH}$ 'sı ile değişebilir $\mathrm{Ca}(\mathrm{r}=0.74 * *)$ arasında pozitif, demir $\left(\mathrm{r}=-0.65^{* *}\right)$ ve alüminyum $\left(\mathrm{r}=0.62^{*}\right)$ ile negatif önemli ilişki bulunmuştur. İyidere-2 lokasyonunda ise toprak pH'sı ile demir $\left(\mathrm{r}=-0.65^{* *}\right)$ ve çinko $\left(\mathrm{r}=-0.55^{* *}\right)$ arasında negatif önemli ilişki tespit edilmiştir.
\end{abstract}

Anahtar Kelimeler: Şlam, kireç, çay, verim, toprak özellikleri

\section{The Effects of Sugar Industry Waste First Carbonification Sludge as Liming Material to Tea Plants the Yield, Quality and Soil Properties}

\begin{abstract}
This study has been carried out in order to determine the changes which the first carbonification sludge will be able to bringout in the chemical structure of the soil and how much will be used in acidic soils in tea plantations in stead of lime. There search have been carried out in three locations with different $\mathrm{pH}$ in Rize Centre and İyidere towns in 2009-2011 years. The plantations have been set up in randomized blocks with three repetitions. In trials, lime and first carbonification sludge has increased tea leaf yield in $\mathrm{P}<0.05$ and $\mathrm{P}<0.01$ importance levels and the highest yield has been obtained from first carbonate sludge application (D subject) as much as the lime requirement. The first carbonification sludge application has increased the fresh tea leaf yield at the rate of 22.9 percentage in Çaykur Research Institute, at the rate of 13.4 percentage in İyidere-1 locationand at the rate of 18.6 in İyidere-2 location. In Çaykur Institute location, positive relationship has been determined between the soil $\mathrm{pH}$ and $\mathrm{Ca}\left(\mathrm{r}=0.53^{*}\right)$ and negative relationship has been determined between the soil $\mathrm{pH}$ and zinc $\left(\mathrm{r}=-0.55^{*}\right)$. In İyidere-1 location, positive relationship has been determined between the soil $\mathrm{pH}$ and changeable $\mathrm{Ca}$ $(\mathrm{r}=0.74 * *)$ and negative relationship has been determined between the soil $\mathrm{pH}$ and aluminum $(\mathrm{r}=-0.62 *)$. In İyidere-2 location, a considerable negative relationship has been determined between the soil $\mathrm{pH}$ and iron $\left(\mathrm{r}=-0.65^{* *}\right)$ and zinc $\left(r=-0.55^{* *}\right)$.
\end{abstract}

Keywords: First carbonification sludge, lime, tea, yield, soil properties 


\section{Giriş}

Bitki besin maddelerinin yarayışlılığı toprak reaksiyonu $(\mathrm{pH})$ ile ilişkilidir. Bir başka deyişle toprak $\mathrm{pH}$ 'sı bitki besin maddelerinin alınabilirliğini önemli ölçüde etkileyen bir toprak özelliğidir. Aşırı yağışlara bağlı yıkanmalar, fizyolojik asit gübrelerin kullanımı ve yoğun tarımsal uğraşlar topraklarda asitleşmeye neden olmaktadır (Kant ve ark., 2006; Barik ve ark., 2013). Önemli bir endüstri bitkisi olan çay ülkemizde Doğu Karadeniz Bölgesi'nde, Araklı'dan başlayıp Gürcistan sınırına kadar uzanan bölgede yetiştirilmektedir. Üretim 77000 hektarlık bir arazide gerçekleştirilmekte ve yaklaşık 225000 aile çay tarımı ile uğraşmaktadır. Çay bitkisi genelde pH 4.5 - 6 arasında olan topraklarda optimum gelişme gösterir. Toprak pH'sı asit ya da alkali yöne doğru gittikçe, bitkinin gelişmesi olumsuz yönde etkilenir (Tekeli, 1962; Eden, 1976; Kacar, 1984; Sarımehmet ve Mahmutoğlu,1991). Özyazıcı ve ark. (2013) çay tarımı yapılan toprakların $\mathrm{pH}$ değişimleri ve alansal olarak dağılımlarını belirlemek amacıyla yaptıkları çalışmada Artvin, Rize ve Trabzon illerini kapsayan 262 adet çay yetiştirilen alandan toprak örnekleri alarak analiz etmişlerdir. Çalışma sonucunda çay tarımı yapılan toprakların $\mathrm{pH}$ değerleri 3.14-6.39 arasında değişiklik gösterdiğini, çay tarım topraklarının \% 86.26'sının çay için ideal kabul edilen sınırların (4.50-6.00) dışında yer aldığı saptamışlardır.

Çay bitkisi asit reaksiyonlu topraklarda yetişmesine karşın aşırı asitlik kesinlikle istenmeyen bir durumdur. Çay üreten ülkelerde kritik toprak pH's1 4.0 olarak saptanmıştır. Toprak pH's1 4.0'ün altına düştüğü zaman gelişme olumsuz şekilde etkilenir ve nitelikli bol yaprak ürünü alınamaz. Niteliksiz çay yapraklarından kaliteli çay elde edilemez. Bu nedenle çay üretici ülkeler çay topraklarında pH'nın optimum düzeyin altına düşmemesine büyük önem verirler (Kacar ve ark., 2004). Toprağın pH değerini yükseltmek için kullanılan kireç, toprağın fiziksel, kimyasal ve mikrobiyolojik özelliklerini etkilemektedir. Buna bağlı olarak topraktaki bazı bitki besin elementleri ve özellikle azot $(\mathrm{N})$, fosfor $(\mathrm{P})$, kalsiyum $(\mathrm{Ca})$ ve magnezyum (Mg)'un bitkiler tarafından alınabilirliği artmaktadır. Düşük pH değerlerinde toksik etki yapabilecek düzeyde çözünürlüğü artan alüminyum ( $\mathrm{Al})$ ve mangan $(\mathrm{Mn})$ gibi bazı bitki besin elementlerinin toksik etkileri, kireç ilavesi ile azalmaktadır (Adiloğlu, 1989; Aydın ve Sezen, 1990; Şimşek, 1998; Kant ve ark., 2006; Barik ve ark., 2013; Şinik, 2011, Chimdi ve ark., 2012, Osundwa ve ark., 2013).
Aşırı yıkanma nedeniyle toprakta eksiklikleri söz konusu olan $\mathrm{Ca}$ ve $\mathrm{Mg}$ gibi elementlerin eksiklikleri giderilmekte, bunlardan başka agregat oluşumu teşvik edilerek geçirgenlik ve havalanma koşulları düzelmektedir. Ayrıca pH değerinin yükselmesi ile topraktaki mikrobiyal faaliyet de artmaktadır. Asit toprakların kireçlenmeleri sonucunda üzerinde yetişen bitkilerdeki manganez ve alüminyumdan ileri gelen toksiklik belirtilerinin kaybolduğu ve ayrıca yapılan yaprak analizlerinde manganez kapsamının azaldığı görülmektedir. Yapılan araştırmalar genellikle $\mathrm{Al}$, demir $(\mathrm{Fe})$ ve $\mathrm{Mn}$ iyonlarının kireçleme ile çökelerek aktif olmayan bir duruma geçtiklerini göstermektedir (Özuygur ve ark., 1974).

Toprak asitliğini gidermede en çok kullanılan kireçleme materyalleri kireç taşı, sönmüş kireç, sönmemiş kireç, dolomit gibi kalsiyum bileşikleridir. $\mathrm{Bu}$ çalışmada kullanılan şlam, pancar şekeri fabrikasyonunda, şerbet arıtımı kademesinde, ham şerbetin kireç sütü $(\mathrm{CaO})$ ile iki kademede kireçlenmesi ve karbondioksitle karbonatlanmasından elde edilen çamurlu şerbetin ayrılması ve koyu çamurun döner filtre veya sıkıştırıcı süzgeçten geçirilmesiyle elde edilen, organik ve inorganik bileşiklerden oluşan bir maddedir (Özen ve Arat, 1999). Şeker sanayi atığ1 şlam fabrikalarımızda ya sulandırılarak pompajla derelere deşarj edilmekte veya çöktürme çukurlarında toplanarak fabrika çevresinde değişik yerlere yığılmaktadır. Sulandırılarak pompajla derelere ve akarsulara verildiğinde içerdiği yüksek miktarda kalsiyum karbonat (\% 70) ve organik madde (\% 10) nedeniyle sulama kalitesini bozmaktadır. Fabrika çevresinde toplananlar ise yığın oluşturarak çeşitli çevre sorunlarına neden olmaktadır (Aksoy ve Danışman, 1989). Bu atığın üretim sonunda fabrika sahasından uzaklaştırılması bazı işletmelere çok pahalıya mal olmaktadır. Bu çalışmada, fabrika sahasındaki bu atığın asit topraklarda çay sahalarında tarım kireci yerine ne kadar kullanılabileceği ve toprağın kimyasal yapısında meydana getirebileceği değişiklikler belirlenmeye çalışılmıştır.

\section{Materyal ve Yöntem}

Araştırma çay tarımının yoğun olarak yapıldığı Rize Merkez ve İyidere ilçesinde olmak üzere 3 lokasyonda 2009-2011 yıllarında yürütülmüştür. Her üç deneme yerine ait deneme öncesi alınan toprakların ve araştırmada kullanılan şeker sanayi atığı şlam materyalinin bazı özellikleri Tablo 1'de verilmiştir. Araştırma yeri toprakları genel tanımlamaya göre; tınlı, kumlu tın, kumlu kil tın bünyeye sahip, kuvvetli/orta dereceli asit, tuzsuz, organik madde yönünden orta seviyede, fosfor bakımından orta/çok yüksek seviyede, potasyum 
Tablo 1. Araştırma toprakları ve şlamın bazı özellikleri

\begin{tabular}{|c|c|c|c|c|c|}
\hline \multicolumn{4}{|l|}{ Toprak } & \multicolumn{2}{|l|}{ Şlam } \\
\hline Özellik & $\begin{array}{r}\text { Çay-Kur } \\
\text { Araştırma }\end{array}$ & İyidere-1 & İyidere-2 & Özellik & Değer \\
\hline Kil, \% & 17.16 & 10.84 & 21.50 & $\mathrm{pH}$ & 8.93 \\
\hline Silt, \% & 32.55 & 35.23 & 18.16 & $\mathrm{EC}, \mathrm{dS} \mathrm{m}{ }^{-1}$ & 1.38 \\
\hline Kum, \% & 50.29 & 53.93 & 60.34 & Kireç, \% & 70.01 \\
\hline Tekstür sınıfi & $\mathrm{L}$ & SL & SCL & Organik madde, \% & 18.00 \\
\hline $\mathrm{pH}$ & 4.70 & 3.51 & 3.70 & Organik karbon, \% & 8.50 \\
\hline Elektriksel iletkenlik (EC), $\mathrm{dS} \mathrm{m}^{-1}$ & 0.176 & 0.312 & 0.267 & Toplam N, \% & 0.412 \\
\hline Kireç $\left(\mathrm{CaCO}_{3}\right), \%$ & --- & --- & --- & Toplam P,\% & 0.399 \\
\hline Organik madde, $\%$ & 2.70 & 2.71 & 2.90 & Toplam K,\% & 0.009 \\
\hline Alinabilir fosfor, $\mathrm{kg} \mathrm{P}_{2} \mathrm{O}_{5} \mathrm{da}^{-1}$ & 25.3 & 26.3 & 8.2 & Toplam $\mathrm{Cu}, \mathrm{mg} \mathrm{kg}^{-1}$ & 21.5 \\
\hline \multirow{5}{*}{ Alınabilir potasyum, $\mathrm{kg} \mathrm{K}_{2} \mathrm{O} \mathrm{da}^{-1}$} & 37.0 & 80.0 & 43.0 & Toplam Zn, mg kg-1 & 12.8 \\
\hline & & & & Toplam Cd, $\mathrm{mg} \mathrm{kg}^{-1}$ & 0.03 \\
\hline & & & & Toplam Ni, mg kg-1 & 1.18 \\
\hline & & & & Toplam $\mathrm{Pb}, \mathrm{mg} \mathrm{kg}^{-1}$ & 0.27 \\
\hline & & & & Toplam Cr, mg kg-1 & 1.81 \\
\hline
\end{tabular}

bakımından ise yeter/fazla düzeyde olduğu belirlenmiştir (Tablo 1). Araştırmada, Çarşamba Şeker Fabrikası atığı şlam ve tarım kireci kullanılmıştır. Şlam materyali $0.03 \mathrm{mg} \mathrm{kg} \mathrm{kg}^{-1}$ kadmiyum (Cd), $9.03 \mathrm{mg} \mathrm{kg}^{-1}$ bakır (Cu), $1.50 \mathrm{mg}$ $\mathrm{kg}^{-1}$ nikel (Ni), $0.21 \mathrm{mg} \mathrm{kg}^{-1}$ kurşun (Pb), $13.0 \mathrm{mg}$ $\mathrm{kg}^{-1}$ çinko (Zn) ve $3.0 \mathrm{mg} \mathrm{kg}^{-1}$ krom (Cr) içermektedir.

Rize ilinin uzun yıllar ortalamalarına ait iklim verileri incelendiğinde; uzun yıllar (41 y1llık) sıcaklık ortalaması $14.2^{\circ} \mathrm{C}$ olup, araştırma yılları sicaklık ortalamasi 14.1-15.3 ${ }^{\circ} \mathrm{C}$ arasinda değişmiştir. Uzun yıllar verileri dikkate alındığında en düşük sıcaklık $3.4{ }^{0} \mathrm{C}$ ile Şubat, en yüksek sıcaklık ise $26.7{ }^{\circ} \mathrm{C}$ ile Ağustos aylarında olmuştur. Araştırma yıllarında aylık toplam yağış miktarı 2009.1-2713.9 mm arasında değişiklik göstermiş olup, 41 yıllık ortalama yağış miktarı ise $2252.9 \mathrm{~mm}$ olarak tespit edilmiştir (Anonim, 2013).

Araştırmada denemeler tesadüf blokları deneme desenine göre 3 tekerrürlü ve çakılı olarak yürütülmüştür. Parsel hasat alanı $6 \mathrm{~m}^{2}$ dir. Araştırmada; kontrol (A), kireç ihtiyacı (K.I) nın tamamının tarım kirecinden (1.0-K.I. Tarım Kireci) karşılandığ 1 konu (B), kireç ihtiyacının yarısının (0.5-K.İ. Şlam), tamamının (1.0-K.İ. Şlam) ve \% 75'inin (1.5-K.İ. Şlam) şlamdan karşılandığı konular (C, D ve E) deneme konuları olarak ele alınmıştır. Yörenin asit toprakları için kireç ihtiyaçlarının belirlenmesinde en uygun yöntem olan Dunn yöntemi (Dunn, 1943) dikkate alınarak toprakların kireç ihtiyaçları tayin edilmiş ve araştırma konularına göre sönmüş kireç miktarları hesaplanmıştır. Toprakların kireç ihtiyacı için pH'yı 5.5'a çıkarmak hedeflenmiştir. Daha sonra hesaplanan kireç miktarı karşılığ1 deneme konularına göre şlam miktarları tespit edilmiştir (Tablo 2). Kireç ve şlam uygulamaları çay bitkisinin sıra aralarına Mart ayı içerisinde uygulanmış ve toprağa karıştırılmıştır.

Gübre kaynağı olarak, kompoze gübre (25-510) kullanılmıştır. Kompoze gübrenin tamamı sıra arasına serpme olarak her yıl Mart ayında uygulanmıştır. Çay bitkisi Mayıs-Ekim ayları arasında $3 \mathrm{kez}$ sürgün döneminde hasadı yapılmıştır. Üçüncü yıl sonunda her sürgün döneminde her parselden ayr1 ayrı yaprak örnekleri alınmıştır. Yeşil çay yapraklarında kuru madde (Anonim, 1990a), polifenol (Anonymous, 1970), selüloz (Anonim, 1989) ve toplam kül (Anonim, 1990b) analizleri yapılmıştır. Araştırmanın 3. yılı sonunda her parselden ayrı ayrı alınan toprak örneklerinde pH (Sağlam, 1978), alınabilir fosfor, alınabilir potasyum, toplam azot, değişebilir $\mathrm{Ca}$, değişebilir Mg Anonymous (1982)'a göre analiz edilmiştir.

Tablo 2. Deneme konularına göre uygulanan kireç ve şlam miktarları

\begin{tabular}{|c|c|c|}
\hline $\begin{array}{l}\text { Çaykur Araştırma } \\
\text { Enstitüsü }\end{array}$ & İyidere-1 & İyidere-2 \\
\hline A.Kontrol & A.Kontrol & A.Kontrol \\
\hline B. $175 \mathrm{~kg} \mathrm{da}^{-1} \mathrm{CaCO}_{3}$ & B. $300 \mathrm{~kg} \mathrm{da}^{-1} \mathrm{CaCO}_{3}$ & B. $275 \mathrm{~kg} \mathrm{da}^{-1} \mathrm{CaCO}_{3}$ \\
\hline C. $125 \mathrm{~kg} \mathrm{da}^{-1}$ şlam & C. $214 \mathrm{~kg} \mathrm{da}^{-1}$ şlam & C. $195 \mathrm{~kg} \mathrm{da}^{-1}$ şlam \\
\hline D. $250 \mathrm{~kg} \mathrm{da}^{-1}$ şlam & D. $428 \mathrm{~kg} \mathrm{da}^{-1}$ şlam & D. $390 \mathrm{~kg} \mathrm{da}^{-1}$ şlam \\
\hline E. $375 \mathrm{~kg} \mathrm{da}^{-1}$ şlam & E. $642 \mathrm{~kg} \mathrm{da}^{-1}$ şlam & E. $585 \mathrm{~kg} \mathrm{da}^{-1}$ şlam \\
\hline
\end{tabular}


Araştırma topraklarının bitkiye yarayışlı mikro element (Fe, $\mathrm{Cu}, \mathrm{Zn}, \mathrm{Mn}$ ) içerikleri ise; Lindsay ve Norvell (1978) tarafından bildirildiği şekilde toprak örnekleri DTPA+TEA (pH: 7.3) ile ekstrakte edildikten sonra, elde edilen süzüklerdeki $\mathrm{Fe}, \mathrm{Cu}, \mathrm{Zn}$ ve $\mathrm{Mn}$ miktarları atomik absorbsiyon spektrofotometresi (Perkin Elmer AAnalyst 300)'nde okunarak tayin edilmiştir.

Yaş çay yaprağı verim değerleri "Jump" istatistik paket programı kullanılarak zamanda bölünmüş parseller deneme desenine göre, deneme konuları arasındaki farklılıklar ise $\mathrm{F}$ ve LSD testleri ile kontrol edilmiştir (Yurtsever, 1984).

\section{Bulgular ve Tartışma}

\subsection{Kireç ve şlam uygulamalarının yaş çay yaprağı verimine etkisi}

Şeker sanayi atığı şlam ve kireç uygulamalarının yaş çay yaprağı verimlerine etkileri Tablo 3, 4 ve 5'te verilmiştir.

Deneme konuları arasında Çaykur Araştırma Enstitüsü ve İyidere-1 lokasyonlarında $\mathrm{P}<0.05$ önem düzeyinde, İyidere-2 lokasyonunda ise $\mathrm{P}<0.01$ önem düzeyinde istatistiki olarak fark bulunmuştur. Çay Araştırma Enstitüsü lokasyonunda yaş çay verimini kireç ve şlam uygulamaları kontrole göre artırmıştır. Kontrolde $1884 \mathrm{~kg} \mathrm{da}^{-1}$ olan yaş çay verimi B konusunda $\% 11.5$ artarak $2128 \mathrm{~kg} \mathrm{da}^{-1}$ olurken, D konusunda \% 22.9 artarak $2442 \mathrm{~kg} \mathrm{da}^{-1}$ 'a yükselmiştir (Tablo 3). İyidere-1 lokasyonunda yaş çay verimindeki kontrol konusuna göre artış B, C ve E konularında birbirine yakın olarak gerçekleşmiştir (Tablo 4).

D konusunda ise artış kontrole göre \% 13.4 olarak gerçekleşmiştir. Her üç lokasyonda da en yüksek yaş çay verimi D konusunda yani kireç ihtiyacının 1.0 katı şlam uygulamasında belirlenmekle beraber İyidere-1 lokasyonunda kontrol konusu dişındaki tüm uygulamalar istatistiki olarak aynı grupta yer almaktadır.

İyidere-2 lokasyonunda ise $\mathrm{D}$ konusunun verimde sağladığı artış \% $\quad 18.6$ olarak gerçekleşmiştir (Tablo 5). Yapılan varyans analizi sonucunda her üç lokasyonda da yıllar arasında $\mathrm{P}<0.01$ önem düzeyinde istatistiki olarak farklılık belirlenmiştir. Çaykur Araştırma Enstitüsü ile İyidere-2 lokasyonlarında yıllara göre verim yükselişi devam etmiş, İyidere-1 lokasyonunda ise denemenin son yılında bir miktar verimde azalış söz konusu olmuştur. Rize yöresinde 1960-1964 yılları arasında yaptığı kireçleme denemesinde Kinez (1964) pH'sı 4.80 olan çay toprağına dekara $250 \mathrm{~kg}$ hesabiyla verilen kirecin $500 \mathrm{~kg}$ kireç uygulamasından daha etkili olduğunu, kireçlemenin ilk üç yıl içerisinde elde olunan ürün miktarı üzerine olumlu ve önemli etki yaptığını, izleyen iki yılda da bu etkinin önemli düzeyde ortadan kalktığını bildirmiştir. Çeşitli araştırmacılar farklı bitkiler üzerinde yaptıkları çalışmalarda kireçlemenin verimi artırdı̆̆ını bildirmişlerdir (Haynes ve Ludecke, 1981; Wijewarda, 2001; Kovacevic ve Rastja, 2010; Effa ve ark., 2012). Verilen kireç ve şlam miktarlarının etkisiyle yükselen toprak pH'sına bağlı olarak verimde önemli derecede artışlar kaydedilmiştir. Hatta bu artış kireç ihtiyacının tamamının şlamdan karşılandığı D konusunda, B konusundan daha fazla olmuştur ki bu da şlamın kapsamında bulunan organik madde ve diğer bitki besin maddelerinden kaynaklandığı söylenebilir.

\subsection{Kireç ve şlam uygulamalarının yaş çay yapraklarının bazı kalite özelliklerine etkisi}

Araştırmanın son yılında çay denemelerinde her hasatta yaprak örnekleri alınmış ve bazı kalite analizleri yapılmıştır. Çaykur araştırma lokasyonuna ait kalite analizleri Tablo 6'da verilmiştir. Çaykur araştırma lokasyonunda deneme konularının kuru madde ve selüloz oranı üzerine etkileri istatistiksel olarak önemsiz bulunurken, sürgün dönemlerinin etkisi istatistiksel olarak $(\mathrm{P}<0.01)$ önemli olmuştur. Kuru madde miktarı en düşük birinci sürgün döneminde (\% 21.96), en yüksek ikinci sürgün döneminde (\% 27.92) gerçekleşmiştir. Üçüncü sürgün döneminde kuru madde miktarı bir miktar azalmıştır. Selüloz oranı \% 8.87-17.48 arasında değişmektedir. Birinci sürgün döneminde selüloz oranı düşük iken ikinci ve üçüncü sürgün dönemlerinde yükselmiştir. Öksüz (1987) sürgün dönemlerinin selüloz oranı üzerinde çok önemli etkiye sahip olduğunu, sürgün dönemleri ilerledikçe selüloz oranının arttığını bildirmiştir.

Polifenol içeriğine deneme konularının, sürgün dönemlerinin, deneme konuları x sürgün dönemi interaksiyonlarının etkileri istatistiksel olarak önemli $(\mathrm{P}<0.01)$ olmuştur. En yüksek polifenol içeriği (\% 27.86) ile birinci sürgün döneminde $\mathrm{E}$ konusunda tespit edilmiştir. En düşük polifenol içeriği \% 15.17 ile A ve B konularında belirlenmiştir. Yaprakların kül içeriği bakımından deneme konuları arasında istatistiksel olarak farklılık bulunmamıştır. Sürgün dönemlerinin yaprakların kül içeriği üzerine etkisi istatistiksel olarak önemli $(\mathrm{P}<0.01)$ bulunmuştur. En düşük kül içeriği \% 4.63 ile ikinci sürgün döneminde belirlenmiştir. Çayda toplam kül miktarı ISO (International Organization for StandardizationUluslararası Standartlar Teşkilâtı) ve TSE (Türk Standartları Enstitüsü) standartlarına göre en az $\% 4$ ve en fazla $\% 8$ olmalıdır (Kacar, 2010). 
Tablo 3. Çaykur Araştırma Enstitüsü lokasyonunda kireç ve şlam uygulamasının yaş çay verimine etkileri $\left(\mathrm{kg} \mathrm{da}^{-1}\right)$

\begin{tabular}{|c|c|c|c|c|}
\hline \multirow{2}{*}{ Konular } & \multicolumn{3}{|c|}{ Yillar } & \multirow{2}{*}{ Ortalama } \\
\hline & 2009 & 2010 & 2011 & \\
\hline A.Kontrol & 1050 & 2178 & 2417 & $1884 \mathrm{~b}$ \\
\hline B. Kireç (1.0 K.İ-Tarım Kireci) & 1318 & 2467 & 2600 & $2128 \mathrm{ab}$ \\
\hline C.(0.5 -K.İ. Şlam) & 1668 & 2256 & 2417 & $2114 \mathrm{ab}$ \\
\hline D.(1.0 -K.İ. Şlam) & 2208 & 2567 & 2550 & $2442 \mathrm{a}$ \\
\hline \multirow[t]{3}{*}{ E.(1.5-K.İ. Şlam) } & 1618 & 2517 & 2583 & $2239 \mathrm{ab}$ \\
\hline & $1572 \mathrm{~b}$ & $2397 \mathrm{a}$ & $2513 \mathrm{a}$ & \\
\hline & \multicolumn{4}{|c|}{15.2} \\
\hline
\end{tabular}

Tablo 4. İyidere-1 lokasyonunda kireç ve şlam uygulamasının yaş çay verimine etkileri $\left(\mathrm{kg} \mathrm{da}^{-1}\right)$

\begin{tabular}{lcccc}
\hline \multirow{2}{*}{ Konular } & \multicolumn{3}{c}{ Y1llar } & \multirow{2}{*}{ Ortalama } \\
\cline { 2 - 4 } & 2009 & 2010 & 2011 & \\
\hline A.Kontrol & 1888 & 3083 & 2650 & $2540 \mathrm{~b}$ \\
B. Kireç (1.0 K.İ-Tarım Kireci) & 2422 & 3256 & 2783 & $2820 \mathrm{a}$ \\
C.(0.5 -K.İ. Slam) & 2216 & 3489 & 2750 & $2818 \mathrm{a}$ \\
D.(1.0 -K.İ. Şlam) & 2655 & 3228 & 2917 & $2933 \mathrm{a}$ \\
E.(1.5 -K.İ. Şlam) & 2178 & 3267 & 2967 & $2804 \mathrm{a}$ \\
\hline \multicolumn{1}{c}{ CV } & & \multicolumn{3}{c}{17.8} \\
\hline
\end{tabular}

Tablo 5. İyidere-2 lokasyonunda kireç ve şlam uygulamasının yaş çay verimine etkileri $\left(\mathrm{kg} \mathrm{da}^{-1}\right)$

\begin{tabular}{lcccc}
\hline \multirow{2}{*}{ Konular } & \multicolumn{3}{c}{ Y1llar } & \multirow{2}{*}{ Ortalama } \\
\cline { 2 - 4 } & 2009 & 2010 & 2011 & \\
\hline A.Kontrol & 1812 & 2256 & 2617 & $2228 \mathrm{~b}$ \\
B. Kireç (1.0 K.̇ं-Tarım Kireci) & 1928 & 2528 & 2917 & $2458 \mathrm{ab}$ \\
C.(0.5 -K.İ. Şlam) & 1855 & 2633 & 2600 & $2363 \mathrm{~b}$ \\
D.(1.0 -K.İ. Şlam) & 2038 & 2922 & 3250 & $2737 \mathrm{a}$ \\
E.(1.5 -K.İ. Şlam) & 1755 & 2883 & 3033 & $2557 \mathrm{ab}$ \\
\hline \multicolumn{1}{c}{ CV } & Yillar $_{\text {ortalama }}$ & $1878 \mathrm{c}$ & $2644 \mathrm{~b}$ & $2883 \mathrm{a}$ \\
\hline
\end{tabular}

İyidere-1 lokasyonunda şeker sanayi atığı şlam ve kireç uygulamalarının yaş çay yaprağının bazı özelliklerine etkileri Tablo 7'de verilmiştir. Yaprakların kuru madde, polifenol ve toplam kül içerikleri bakımından deneme konuları arasında istatistiksel anlamda farklılık bulunmamıştır. Bu özellikler bakımından sürgün dönemleri arasında $\mathrm{P}<0.01$ önem düzeyinde istatistiksel olarak farklılık tespit edilmiştir. Kuru madde miktarı birinci sürgün döneminde diğer sürgün dönemlerine göre daha düşük olup, polifenol miktarı ise birinci sürgün döneminde diğer dönemlerden yüksek olarak belirlenmiştir. Bir çok araştırmada polifenol değerinin birinci sürgünde yüksek olduğunu, diğer sürgün dönemlerinde polifenol içeriğinin düştüğü bildirilmektedir (Öksüz, 1987; Taban ve ark., 2000; Taban ve ark., 2001; Müftüoğlu ve ark., 2010). Polifenoller çay yaprağının siyah çaya işlenmesi aşamalarında çayın özellik kazanmasında önemli rol oynaması nedeniyle yaprağın toplam polifenol içeriğinin yüksek olması istenmektedir. Çay bitkisinde polifenol içeriğinin genç yapraktan yaşlı yaprağa doğru azaldığı dikkate alındığında üçüncü hasat döneminde yaprağın toplam polifenol içeriklerinin azalması doğal sonuç olarak görülmektedir. Toplam kül içeriği sürgün dönemlerine göre değişiklik göstermiş, en yüksek kül içeriği \% 6.16 ile üçüncü sürgün döneminde belirlenmiştir. Yaprakların selüloz içeriğine sürgün dönemlerinin etkisi istatistiksel olarak $\mathrm{P}<0.01$ düzeyinde, deneme konuları $\mathrm{x}$ sürgün dönemi interaksiyonlarının etkisi ise $\mathrm{P}<0.05$ düzeyinde önemli bulunmuştur. En yüksek selüloz oranı üçüncü sürgün döneminde $\mathrm{A}, \mathrm{C}$ ve $\mathrm{D}$ konularında belirlenmekle birlikte aynı sürgün döneminin $\mathrm{B}$ ve E konuları ile arasında istatistiki olarak farklılık bulunmamaktadır. En düşük selüloz oranı ise birinci sürgün döneminde kontrol ve kireç uygulamalarında $\quad(\% \quad 11.98$ ve 13.27$)$ gerçekleşmiştir.

İyidere-2 lokasyonunda kireç ve şlam uygulamalarının yaş çay yaprağının bazı kalite özelliklerine etkileri Tablo 8'de verilmiştir. Kuru madde oranı bakımından uygulamalar arasında önemli farklılık bulunmazken, sürgün dönemleri arasında $\mathrm{P}<0.01$ önem seviyesinde farkl1lık 
bulunmuştur. Kuru madde oranı en düşük birinci sürgün döneminde gerçekleşmiştir. Selüloz oranı ve polifenol içeriklerine uygulamaların etkisi önemli bulunmazken, sürgün dönemi, deneme konuları $\mathrm{x}$ sürgün dönemi interaksiyonlarının birlikte etkileri $\mathrm{P}<0.01$ düzeyinde istatistiksel olarak önemli bulunmuştur. Selüloz oranı birinci ve ikinci sürgün dönemlerinde düşük olup, üçüncü sürgün döneminde artış göstermektedir. Deneme konuları $\mathrm{x}$ sürgün dönemleri interaksiyonu incelendiğinde, en yüksek selüloz oranı \% 19.81 ile üçüncü sürgün döneminde $\mathrm{B}$ konusunda, en düşük selüloz içeriği ise \% 15.12 ile birinci sürgün döneminde A konusunda tespit edilmiştir. Polifenol oranı \% $11.67-22.00$ arasında değişmiştir. En düşük polifenol oranı \% 11.67 ile üçüncü sürgün döneminde $\mathrm{E}$ konusunda gerçekleşmiştir. En yüksek polifenol oranı ise ikinci sürgün döneminde $\mathrm{C}$ konusunda belirlenmekle birlikte, $\mathrm{D}$ ve $\mathrm{E}$ konuları ile aralarında istatistiki olarak farklılık bulunmamaktadır. Toplam kül içeriği bakımından uygulamalar arasında farklılık bulunmamakta, sürgün dönemleri arasında $\mathrm{P}<0.01$ önem seviyesinde farklılık bulunmaktadır. Kül içeriği diğer lokasyonlarda olduğu gibi en yüksek üçüncü sürgün döneminde tespit edilmiştir.

\subsection{Kireç ve şlam uygulamalarının toprakların bazı kimyasal özelliklerine etkisi}

Araştırmanın son yılında tüm lokasyonlarda üçüncü hasat sonrasında $0-20 \mathrm{~cm}$ derinlikten alınan toprak örneklerinde $\mathrm{pH}$, alınabilir fosfor, alınabilir potasyum, toplam azot, değişebilir kalsiyum ve magnezyum, bitkiye yarayışlı demir, bakır, çinko, mangan ile alüminyum analizleri yapılmış ve toprak pH'sı ile bunların arasında ilişki incelenmiş, Tablo 9 ve 10 'da verilmiştir. Kireç ve şlam uygulamalarının çay bitkisinin verim ve bazı kalite özellikleri ile toprağın bazı kimyasal özellikleri üzerine olumlu etkide bulunduğu belirlenmiştir. Çay için en uygun pH sınırı 4.5-6.0 olarak kabul edilmektedir. $\mathrm{Bu}$ araştırmada çay denemelerinin yürütüldüğü iki lokasyonda çay için (İyidere-1 ve İyidere-2) en iyi kabul edilen alt sınırın (4.5) altında yer almaktadır. Verilen kireç ve şlam miktarlarının etkisiyle yükselen toprak pH'sına bağlı olarak verimde önemli derecede artışlar kaydedilmiştir.

Tablo 6. Çaykur Araştırma Enstitüsü lokasyonunda kireç ve şlam uygulamasının yaş çay yapraklarının bazı kalite özelliklerine etkileri

\begin{tabular}{|c|c|c|c|c|c|}
\hline & \multirow[t]{2}{*}{ Konular } & \multicolumn{3}{|c|}{ Sürgün Dönemleri } & \multirow[t]{2}{*}{ Ortalama } \\
\hline & & I. Sürgün & II. Sürgün & III. Sürgün & \\
\hline \multirow{6}{*}{$\begin{array}{l}\text { Kuru madde } \\
\qquad(\%)\end{array}$} & A & 22.73 & 27.73 & 26.43 & 25.63 \\
\hline & B & 23.20 & 27.60 & 26.70 & 25.83 \\
\hline & $\mathrm{C}$ & 21.87 & 28.53 & 26.33 & 25.58 \\
\hline & $\mathrm{D}$ & 21.47 & 27.87 & 27.70 & 25.68 \\
\hline & $\mathrm{E}$ & 20.53 & 27.87 & 25.70 & 24.70 \\
\hline & Ortalama & $21.96 \mathrm{c}$ & $27.92 \mathrm{a}$ & $26.57 \mathrm{~b}$ & \\
\hline \multirow{6}{*}{$\begin{array}{l}\text { Selüloz } \\
(\%)\end{array}$} & A & 8.93 & 17.35 & 17.32 & 14.53 \\
\hline & B & 9.12 & 16.47 & 17.14 & 14.24 \\
\hline & $\mathrm{C}$ & 9.08 & 15.26 & 16.61 & 13.65 \\
\hline & $\mathrm{D}$ & 8.87 & 15.65 & 17.48 & 14.00 \\
\hline & $\mathrm{E}$ & 9.72 & 17.34 & 16.08 & 14.38 \\
\hline & Ortalama & $9.14 \mathrm{~b}$ & $16.41 \mathrm{a}$ & $16.93 \mathrm{a}$ & \\
\hline \multirow{6}{*}{$\begin{array}{l}\text { Polifenol } \\
\text { (\%) }\end{array}$} & A & $17.64 \mathrm{de}$ & $15.17 \mathrm{e}$ & $18.75 \mathrm{de}$ & $17.51 \mathrm{C}$ \\
\hline & B & $17.93 \mathrm{de}$ & $15.17 \mathrm{e}$ & $17.29 \mathrm{de}$ & $16.79 \mathrm{C}$ \\
\hline & $\mathrm{C}$ & $21.56 \mathrm{bc}$ & $17.03 \mathrm{de}$ & $18.78 \mathrm{~cd}$ & $19.12 \mathrm{AB}$ \\
\hline & $\mathrm{D}$ & $24.67 \mathrm{ab}$ & $15.55 \mathrm{de}$ & $17.00 \mathrm{de}$ & $19.07 \mathrm{~B}$ \\
\hline & $\mathrm{E}$ & $27.86 \mathrm{a}$ & $16.72 \mathrm{de}$ & $17.04 \mathrm{de}$ & $20.84 \mathrm{~A}$ \\
\hline & Ortalama & $21.93 \mathrm{~A}$ & $16.31 \mathrm{~B}$ & $17.77 \mathrm{~B}$ & \\
\hline \multirow{6}{*}{$\begin{array}{l}\text { Kül } \\
(\%)\end{array}$} & A & 5.47 & 4.48 & 5.59 & 5.18 \\
\hline & B & 5.67 & 4.75 & 5.60 & 5.34 \\
\hline & $\mathrm{C}$ & 5.35 & 4.33 & 5.40 & 5.03 \\
\hline & D & 5.49 & 4.72 & 5.56 & 5.26 \\
\hline & $\mathrm{E}$ & 5.93 & 4.89 & 5.58 & 5.47 \\
\hline & Ortalama & $5.58 \mathrm{a}$ & $4.63 \mathrm{~b}$ & $5.55 \mathrm{a}$ & \\
\hline
\end{tabular}

A: Kontrol, B: Kireç (1.0-K.İ.-Tarım Kireci), C: (0.5-K.İ.-Şlam), D: (1.0-K.İ.-Şlam), E: (1.5-K.İ.-Şlam) 
Tablo 7. İyidere-1 lokasyonunda kireç ve şlam uygulamasının yaş çay yapraklarının bazı kalite özelliklerine etkileri

\begin{tabular}{|c|c|c|c|c|c|}
\hline & \multirow[t]{2}{*}{ Konular } & \multicolumn{3}{|c|}{ Sürgün Dönemleri } & \multirow[t]{2}{*}{ Ortalama } \\
\hline & & I. Sürgün & II. Sürgün & III. Sürgün & \\
\hline \multirow{6}{*}{$\begin{array}{c}\text { Kuru madde } \\
(\%)\end{array}$} & A & 20.07 & 25.20 & 24.90 & 23.39 \\
\hline & B & 20.07 & 24.20 & 24.30 & 22.86 \\
\hline & $\mathrm{C}$ & 19.07 & 24.00 & 24.67 & 22.58 \\
\hline & D & 20.00 & 25.93 & 24.76 & 23.57 \\
\hline & E & 19.33 & 24.40 & 25.27 & 23.00 \\
\hline & Ortalama & 19.71 & 24.75 & 24.78 & \\
\hline \multirow{6}{*}{$\begin{array}{c}\text { Selüloz } \\
(\%)\end{array}$} & A & $11.98 \mathrm{~d}$ & $17.40 \mathrm{c}$ & $20.35 \mathrm{a}$ & 16.57 \\
\hline & B & $13.27 \mathrm{~d}$ & $18.19 b c$ & $20.12 a b$ & 17.19 \\
\hline & $\mathrm{C}$ & $16.29 \mathrm{c}$ & $16.49 \mathrm{c}$ & $21.42 \mathrm{a}$ & 18.07 \\
\hline & $\mathrm{D}$ & $16.52 \mathrm{c}$ & $16.90 \mathrm{c}$ & $21.72 \mathrm{a}$ & 18.38 \\
\hline & E & $16.76 \mathrm{c}$ & $17.13 \mathrm{c}$ & $20.01 \mathrm{ab}$ & 17.97 \\
\hline & Ortalama & $14.96 \mathrm{C}$ & $17.22 \mathrm{~B}$ & $20.73 \mathrm{~A}$ & \\
\hline \multirow{6}{*}{$\begin{array}{l}\text { Polifenol } \\
(\%)\end{array}$} & A & 21.15 & 16.02 & 17.97 & 18.38 \\
\hline & B & 17.04 & 17.41 & 17.18 & 17.21 \\
\hline & $\mathrm{C}$ & 20.14 & 19.18 & 16.14 & 18.49 \\
\hline & D & 22.57 & 20.35 & 17.97 & 20.29 \\
\hline & E & 20.38 & 23.47 & 16.66 & 20.17 \\
\hline & Ortalama & 20.25 & 19.29 & 17.18 & \\
\hline \multirow{6}{*}{$\begin{array}{l}\text { Kül } \\
(\%)\end{array}$} & $\bar{A}$ & 5.59 & 5.16 & 6.11 & 5.62 \\
\hline & B & 5.74 & 5.62 & 6.04 & 5.80 \\
\hline & $\mathrm{C}$ & 5.62 & 5.68 & 6.15 & 5.82 \\
\hline & $\mathrm{D}$ & 5.26 & 5.28 & 6.15 & 5.56 \\
\hline & E & 5.34 & 4.94 & 6.34 & 5.54 \\
\hline & Ortalama & $5.51 \mathrm{~b}$ & $5.34 \mathrm{~b}$ & $6.16 \mathrm{a}$ & \\
\hline
\end{tabular}

Tablo 8. İyidere-2 lokasyonunda kireç ve şlam uygulamasının yaş çay yapraklarının bazı kalite özelliklerine etkileri

\begin{tabular}{|c|c|c|c|c|c|}
\hline & \multirow{2}{*}{ Konular } & \multicolumn{3}{|c|}{ Sürgün Dönemleri } & \multirow{2}{*}{ Ortalama } \\
\hline & & I. Sürgün & II. Sürgün & III. Sürgün & \\
\hline \multirow{6}{*}{$\begin{array}{c}\text { Kuru madde } \\
(\%)\end{array}$} & $\mathrm{A}$ & 19.13 & 24.67 & 25.30 & 23.03 \\
\hline & $\mathrm{B}$ & 19.37 & 26.27 & 23.53 & 23.06 \\
\hline & $\mathrm{C}$ & 18.93 & 24.20 & 25.70 & 22.94 \\
\hline & $\mathrm{D}$ & 19.10 & 25.07 & 25.33 & 23.17 \\
\hline & E & 18.73 & 24.53 & 25.52 & 22.93 \\
\hline & Ortalama & $19.05 \mathrm{~b}$ & $24.95 \mathrm{a}$ & $25.07 \mathrm{a}$ & \\
\hline \multirow{6}{*}{$\begin{array}{c}\text { Selüloz } \\
(\%)\end{array}$} & $\mathrm{A}$ & $15.12 \mathrm{~g}$ & 16.45 ef & $19.43 \mathrm{ab}$ & 17.00 \\
\hline & $\mathrm{B}$ & $15.78 \mathrm{fg}$ & $16.96 \mathrm{def}$ & $19.81 \mathrm{a}$ & 17.52 \\
\hline & $\mathrm{C}$ & $15.80 \mathrm{fg}$ & $16.26 \mathrm{efg}$ & $19.68 \mathrm{ab}$ & 17.25 \\
\hline & $\mathrm{D}$ & $18.59 \mathrm{bc}$ & $16.69 \mathrm{def}$ & $18.89 \mathrm{abc}$ & 18.06 \\
\hline & $\mathrm{E}$ & $17.37 \mathrm{de}$ & $17.73 \mathrm{~cd}$ & $19.04 \mathrm{ab}$ & 18.05 \\
\hline & Ortalama & $16.53 \mathrm{~B}$ & $16.82 \mathrm{~B}$ & $19.37 \mathrm{~A}$ & \\
\hline \multirow{6}{*}{$\begin{array}{l}\text { Polifenol } \\
\quad(\%)\end{array}$} & $\mathrm{A}$ & 17.06 defg & $18.58 \mathrm{cde}$ & $17.53 \mathrm{cdef}$ & 17.72 \\
\hline & $\mathrm{B}$ & 17.49 defg & $15.94 \mathrm{fgh}$ & $15.03 \mathrm{gh} 1$ & 16.15 \\
\hline & $\mathrm{C}$ & $16.36 \mathrm{efg}$ & $22.00 \mathrm{a}$ & 13.49 hij & 17.28 \\
\hline & $\mathrm{D}$ & $19.29 \mathrm{bcd}$ & $21.49 \mathrm{ab}$ & $12.84 \mathrm{ij}^{\circ}$ & 17.87 \\
\hline & E & $18.10 \mathrm{cdef}$ & $19.99 \mathrm{abc}$ & $11.67 \mathrm{j}$ & 16.59 \\
\hline & Ortalama & $17.66 \mathrm{~B}$ & $19.60 \mathrm{~A}$ & $14.11 \mathrm{C}$ & \\
\hline \multirow{6}{*}{$\begin{array}{l}\text { Kül } \\
(\%)\end{array}$} & $\mathrm{A}$ & 5.64 & 5.28 & 6.69 & 5.87 \\
\hline & B & 5.92 & 5.36 & 6.41 & 5.90 \\
\hline & $\mathrm{C}$ & 5.58 & 5.36 & 6.22 & 5.72 \\
\hline & $\mathrm{D}$ & 5.43 & 5.32 & 6.22 & 5.66 \\
\hline & E & 5.41 & 5.42 & 5.93 & 5.59 \\
\hline & Ortalama & $5.60 \mathrm{~b}$ & $5.35 \mathrm{~b}$ & $6.29 \mathrm{a}$ & \\
\hline
\end{tabular}

A: Kontrol, B: Kireç (1.0-K.İ.-Tarım Kireci), C: (0.5-K.İ.-Şlam), D: (1.0-K.İ.-Şlam), E: (1.5-K.İ.-Şlam) 
Tablo 9. Hasat sonrası alınan araştırma topraklarının bazı kimyasal özellikleri

\begin{tabular}{|c|c|c|c|c|c|c|c|c|c|c|c|}
\hline \multirow[t]{2}{*}{ Konular } & \multirow[t]{2}{*}{$\mathrm{pH}$} & \multicolumn{2}{|c|}{$\begin{array}{c}\text { Alınabilir } \\
\left(\mathrm{kg} \mathrm{da}^{-1}\right)\end{array}$} & \multirow[t]{2}{*}{$\begin{array}{l}\text { Azot } \\
(\%)\end{array}$} & \multicolumn{2}{|c|}{$\begin{array}{c}\text { Değişebilir } \\
\left(\mathrm{meq} \mathrm{100g}^{-1}\right)\end{array}$} & \multicolumn{5}{|c|}{ Alınabilir mikro elementler $\left(\mathrm{mg} \mathrm{kg}^{-1}\right)$} \\
\hline & & $\mathrm{P}_{2} \mathrm{O}_{5}$ & $\mathrm{~K}_{2} \mathrm{O}$ & & $\mathrm{Ca}$ & $\mathrm{Mg}$ & $\mathrm{Fe}$ & $\mathrm{Cu}$ & $\mathrm{Zn}$ & $\mathrm{Mn}$ & $\mathrm{Al}$ \\
\hline \multicolumn{12}{|c|}{ Çaykur Araştırma Enstitüsü } \\
\hline A & 4.70 & 27.9 & 79 & 0.18 & 12.67 & 2.35 & 50.07 & 0.56 & 4.49 & 4.72 & 628 \\
\hline B & 4.79 & 45.9 & 106 & 0.22 & 14.26 & 2.58 & 30.09 & 1.31 & 3.53 & 4.66 & 420 \\
\hline $\mathrm{C}$ & 4.81 & 40.6 & 77 & 0.17 & 11.07 & 1.88 & 37.14 & 1.76 & 2.65 & 6.87 & 547 \\
\hline $\mathrm{D}$ & 4.76 & 50.6 & 87 & 0.16 & 15.46 & 2.27 & 28.71 & 1.25 & 3.14 & 4.63 & 589 \\
\hline E & 5.09 & 50.5 & 86 & 0.17 & 18.56 & 2.80 & 21.66 & 0.56 & 1.14 & 5.89 & 249 \\
\hline \multicolumn{12}{|c|}{ İyidere-1 lokasyonu } \\
\hline A & 3.65 & 28.0 & 90 & 0.26 & 1.79 & 0.85 & 66.46 & 2.19 & 1.87 & 26.10 & 1577 \\
\hline B & 4.05 & 41.5 & 81 & 0.25 & 2.75 & 1.39 & 51.39 & 0.76 & 2.60 & 45.95 & 948 \\
\hline $\mathrm{C}$ & 3.67 & 39.8 & 69 & 0.23 & 2.47 & 1.22 & 54.43 & 0.64 & 2.36 & 19.57 & 1389 \\
\hline $\mathrm{D}$ & 3.62 & 36.4 & 73 & 0.28 & 2.32 & 1.53 & 63.83 & 0.70 & 0.50 & 16.4 & 834 \\
\hline $\mathrm{E}$ & 4.34 & 40.7 & 85 & 0.28 & 3.08 & 1.36 & 45.89 & 1.29 & 0.81 & 29.16 & 636 \\
\hline \multicolumn{12}{|c|}{ İyidere-2 lokasyonu } \\
\hline A & 3.51 & 19.8 & 55 & 0.17 & 0.86 & 0.67 & 62.90 & 0.42 & 0.82 & 6.79 & 1167 \\
\hline B & 3.88 & 27.4 & 56 & 0.14 & 2.57 & 0.62 & 35.52 & 0.41 & 0.59 & 13.84 & 817 \\
\hline $\mathrm{C}$ & 3.71 & 15.6 & 52 & 0.12 & 3.69 & 0.76 & 35.52 & 0.38 & 0.66 & 30.11 & 1247 \\
\hline D & 3.75 & 18.9 & 57 & 0.12 & 3.95 & 0.68 & 29.00 & 0.54 & 0.73 & 5.36 & 701 \\
\hline E & 4.02 & 25.3 & 55 & 0.19 & 3.48 & 0.86 & 33.63 & 0.36 & 0.35 & 5.40 & 754 \\
\hline
\end{tabular}

Yapılan korelasyon analizi sonucunda, Çaykur araştırma lokasyonunun toprak pH'sı ile değişebilir kalsiyum $(\mathrm{r}=0.53 *)$ arasında pozitif, çinko $\left(\mathrm{r}=-0.55^{*}\right)$ ile negatif önemli ilişki belirlenmiştir (Tablo 10, Şekil 1 ve 2). Toprak pH'sı ile fosfor, potasyum, azot, değişebilir magnezyum, demir bakır, mangan ve alüminyum arasında istatistiksel önemli bir ilişki bulunamamıştır (Tablo 10).

Tablo 10. Araştırma topraklarının bazı kimyasal özellikleri ile $\mathrm{pH}$ arasındaki korelasyon katsayıları

\begin{tabular}{lccc}
\hline \multirow{2}{*}{ Özellikler } & \multicolumn{3}{c}{ Korelasyon katsay1s1 } \\
\cline { 2 - 4 } & $\begin{array}{c}\text { Çaykur } \\
\text { Araştırma } \\
\text { Enstitüsü }\end{array}$ & $\begin{array}{c}\text { İyidere-1 } \\
\text { lokasyonu }\end{array}$ & $\begin{array}{c}\text { İyidere-2 } \\
\text { lokasyonu }\end{array}$ \\
\hline pH- fosfor & 0.39 & 0.13 & 0.23 \\
pH- potasyum & 0.08 & 0.25 & 0.20 \\
pH- azot & 0.07 & 0.14 & 0.20 \\
pH- değişebilir Ca & $0.53^{*}$ & $0.74^{* *}$ & 0.41 \\
pH- değişebilir Mg & 0.32 & 0.21 & 0.05 \\
pH- demir & -0.47 & $-0.65^{* *}$ & $-0.65^{* *}$ \\
pH- bakır & -0.05 & -0.11 & -0.15 \\
pH- çinko & $-0.55^{*}$ & 0.01 & $-0.55^{* *}$ \\
pH- mangan & 0.26 & 0.40 & -0.19 \\
pH- alüminyum & -0.43 & $-0.62^{*}$ & -0.44 \\
\hline *: p<0.05, ** p $<0.01$ & \multicolumn{3}{l}{}
\end{tabular}

Toprak pH'sı ile yarayışlı demir, bakır ve alüminyum arasında istatistiksel bir farklılık olmamasına rağmen $\mathrm{pH}$ arttıkça demir, bakır ve alüminyumun azaldığı, manganın ise $\operatorname{arttığ} 1$ görülmektedir.

İyidere-1 lokasyonunda toprak $\mathrm{pH}$ 's1 ile değişebilir kalsiyum $(\mathrm{r}=0.74 * *)$ arasında pozitif, demir $\left(\mathrm{r}=-0.65^{* *}\right)$ ve alüminyum $\left(\mathrm{r}=0.62^{*}\right)$ negatif önemli ilişki belirlenmiştir (Tablo 10, Şekil 3,4 ve 5). Toprak pH's1 ile fosfor, potasyum, azot, değişebilir magnezyum, bakır, çinko, mangan arasında istatistiksel önemli bir ilişki bulunamamıştır (Tablo 10).

İyidere-2 lokasyonunda toprak pH's1 ile bazı kimyasal özellikler arasındaki ilişki Tablo 10'da verilmiştir. Toprak pH'sı ile demir $\left(\mathrm{r}=-0.65^{* *}\right)$ ve çinko $\left(\mathrm{r}=-0.55^{* *}\right)$ arasında negatif önemli ilişki belirlenmiştir (Tablo 10, Şekil 6 ve 7). Toprak pH's1 ile fosfor, potasyum, azot, değişebilir kalsiyum, değişebilir magnezyum, bakır, mangan ve alüminyum arasında istatistiksel önemli bir ilişki bulunamamıştır. Toprak pH'sı ile değişebilir kalsiyum ve alüminyum arasında istatistiksel bir farklılık olmamasına rağmen $\mathrm{pH}$ arttıkça değişebilir kalsiyumun artma eğilimi ve alüminyumun ise azalma eğilimi gösterdiği görülmektedir. Asit topraklarda kireçlemenin makro ve mikro element içeriklerinin araştırıldığ 1 benzer çalışmalarda toprak pH'sının artışına bağlı olarak alınabilir demir, bakır, çinko, mangan ile değişebilir alüminyum miktarının azaldığ1 bildirilmiştir (Aydın ve Sezen, 1990; Martini ve Mutter, 1985a ve 1985b; Sürücü, 1995).

Kireç ilavesinin toprak pH'sını artırdığını çeşitli araştırmacılar bildirmişlerdir. Ülgen ve ark. (1967), toprak pH'sını yükseltmede Doğu Karadeniz Bölgesi topraklarında yaptıkları çalışmalarla şlamın kireçten daha etkili olduğunu saptamışlardır. Fosfor toprak reaksiyonundan en fazla etkilenen bitki besin elementidir. Toprakta fosfor fiksasyonuna toprakta bulunan kil tipi ve miktarı, toprak pH'sı, organik madde miktarı ve kireç gibi etmenler etki eder. Çeşitli araştırıcılar 
asit topraklara kireç ilavesi ile fosfor elverişliliğinin arttığını ancak kireç ihtiyaçtan fazla miktarda uygulandığında verilen kirecin fosfor fiksasyonunu artırarak bitkiler tarafından azalttığını ileri sürmüşlerdir. Bu çalışmada kireç ve şlam uygulamalarının ortam pH'sını yükseltmesi ile fosfor miktarının kontrol konusuna göre arttığ her üç lokasyonda da görülmektedir (Tablo 9). Topraktaki potasyumun dinamik yapısını toprağın tekstürü, organik madde, donma-çözülme, ıslanma-kuruma, kireç ve pH'nın etkilediği bilinmektedir. Çaykur araştırma ve İyidere-1 lokasyonlarında kireç ve şlam uygulamalarından topraktaki potasyum miktarının İyidere-2 lokasyonundan daha fazla etkilenmesini de açıklamaktadır. Çaykur araştırma ve İyidere lokasyonları tınlı bünyeye sahip iken İyidere-2 lokasyonu kumlu killi tın bünyeye sahiptir (Tablo 1). Toprakların kireç, $\mathrm{pH}$ ve diğer bazı özellikleri toprakta potasyumun serbest birakilmasina veya tutulmasına tesir ettiği bilinmektedir. Ülgen ve ark. (1967), Ateşalp (1976), Haynes ve Ludecke (1981), Şimşek (1998), Shamshuddin ve ark. (2004), Kant ve ark. (2006), Şinik (2011) ve Osundwa ve ark. (2013) toprak pH'sı ve diğer özellikler arasında benzer sonuçları bulmuşlardır.

Çay topraklarının değişik özellikleri ile alüminyum içerikleri arasında ilişkiyi araştıran Kacar ve ark. (1979), pH ile alüminyum arasında güvenilir düzeyde önemli ilişki bulmuşlardır. $\mathrm{Bu}$ durum pH yükseldikçe çözünebilir alüminyum miktarının azalmakta olduğunu göstermektedir. Çay topraklarının yarayışı fosfor içerikleri ile alüminyum içerikleri arasında da benzer ilişki saptanmıştır. Alüminyum topraklarda fosforu, çözünemez organik ve inorganik fosfatlar haline dönüştürerek bitkiye yarayışsız şekle sokmaktadır.

\section{Sonuçlar}

Doğu Karadeniz Bölgesi'nde çay yetiştirilen toprakların $\mathrm{pH}$ değerlerinin çok değişken olması, toprakların fosfor ve potasyum düzeylerinin yüksek olması nedeni ile genel bir gübreleme uygulamasından çok toprak analizine dayalı gübreleme yapılmasının gerektiği ortaya çıkmıştır. $\mathrm{Bu}$ çalışmanın sonuçları da göstermiştir ki toprak reaksiyonunun düşük olması çay bitkisinde alüminyum gibi elementlerin birikmesine neden olabileceği düşünülerek bu elementin de takip edilmesinde yarar bulunmaktadır. Toprak pH'sının düşük olduğu çay bahçelerinde kireçleme materyali olarak şlamın kirece alternatif olabileceği tespit edilmiştir. Kullanılacak şlam miktarı çay toprağının pH'sına bağlı olarak değişeceğinden kireç ihtiyacı belirlenerek bunun karşılığı kadar şlam uygulanabilir. Ülkemizde genellikle asit topraklar Karadeniz, Trakya ve Marmara bölgelerinde bulunmakta ise de son yıllarda yapılan çalışmalarda hemen hemen her ilimizde az veya çok asit reaksiyonlu toprak bulunduğu ve bunların nötralizasyonu için de oldukça fazla miktarda kirece ihtiyaç bulunduğu bilinmektedir. Şeker fabrikaları şlam materyalini (döner çamuru), dere veya göllere boşaltmakta ya da fabrika etrafinda biriktirmekte, bu durum çevre kirliliği sorununu da beraberinde getirmektedir. Şeker sanayi atığ 1 şlam materyali paketlenerek asit topraklarda toprak düzenleyici olarak kullanıldığ 1 takdirde fabrikalar için önemli bir sorun teşkil eden bu materyal değerlendirilmiş olacaktır.

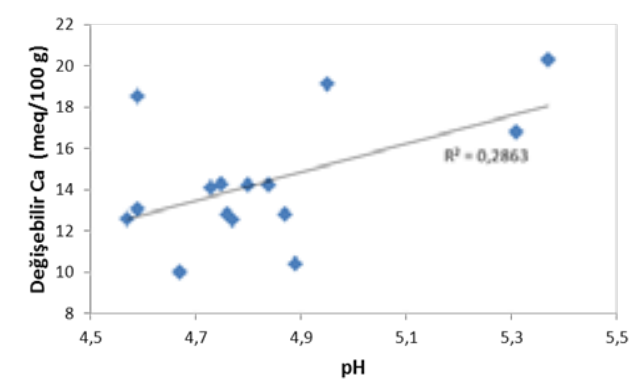

Şekil 1. Çaykur Araştırma Enstitüsü lokasyonunda $\mathrm{pH}$ ile değişebilir $\mathrm{Ca}$ arasındaki ilişki

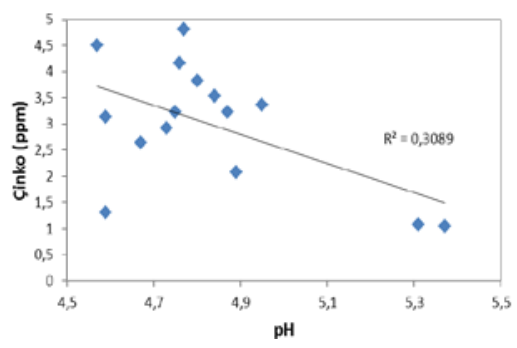

Şekil 2. Çaykur Araştırma Enstitüsü lokasyonunda pH ile çinko arasındaki ilişki 


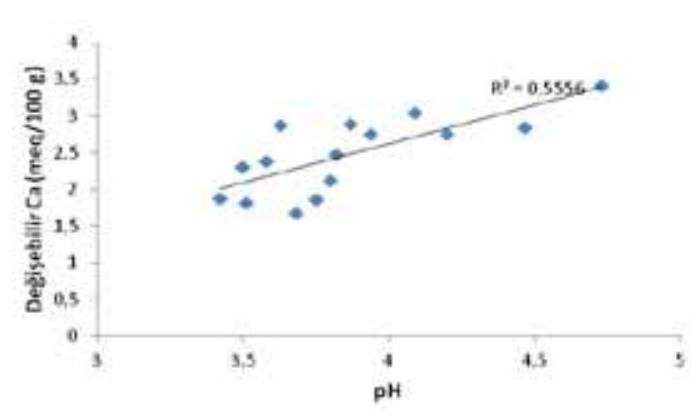

Şekil 3. İyidere-1 lokasyonunda pH ile değişebilir $\mathrm{Ca}$ arasındaki ilişki

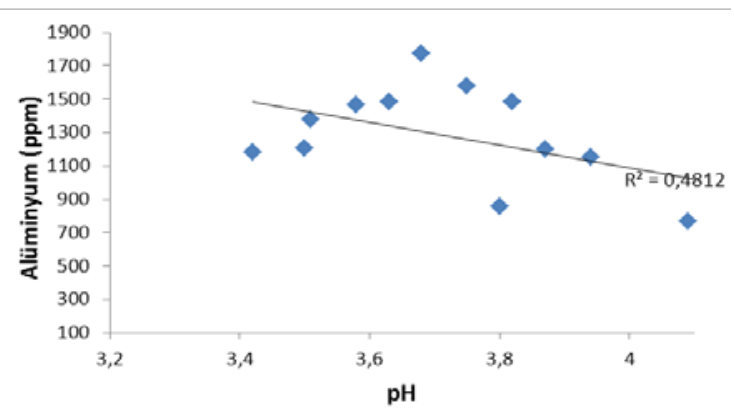

Şekil 5. İyidere-1 lokasyonunda $\mathrm{pH}$ ile alüminyum arasındaki ilişki

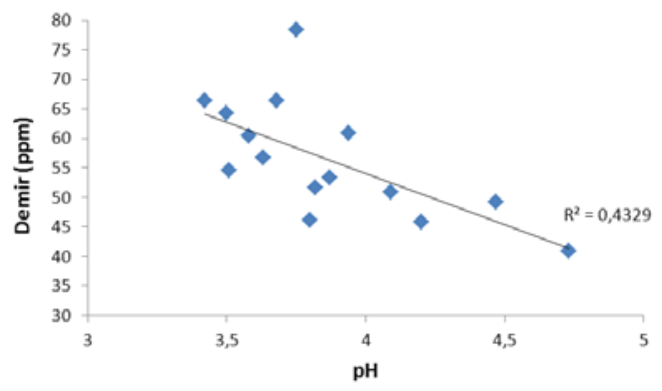

Şekil 4. İyidere-1 lokasyonunda $\mathrm{pH}$ ile demir arasındaki ilişki

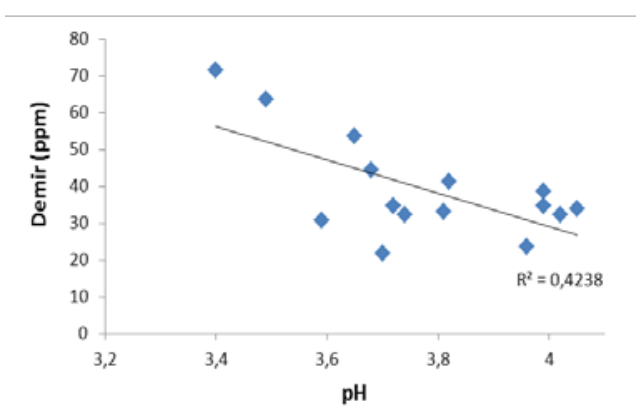

Şekil 6. İyidere-2 lokasyonunda $\mathrm{pH}$ ile demir arasındaki ilişki

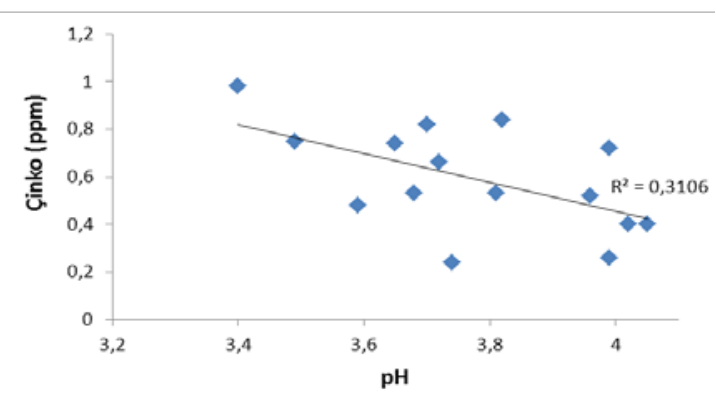

Şekil 7. İyidere-2 lokasyonunda pH ile çinko arasındaki ilişki

\section{Kaynaklar}

Adiloğlu, A., 1989. Trakya bölgesi asit topraklarına kireç ilavesinin bazı makro besin elementlerinin elverişliliğine etkisi üzerinde bir araştırma. Trakya Üniversitesi, Fen Bilimleri Enstitüsü, $53 \mathrm{~s}$. Tekirdağ.

Aksoy, T., Danışman, S., 1989. Döner çamurunun kireçleme amacıyla kullanılması üzerine bir araştırma. Toprak İlmi Derneği, 10. Bilimsel Toplantı Tebliğleri, s. 43-45.

Anonim, 1989. TS 6932, 'G1da Maddelerinde Ham Selüloz Tayini', Genel Metot, Türk Standartları
Enstitüsü, Necatibey Caddesi, No:112, Bakanlıklar, Ankara.

Anonim, 1990a. TS 1561, 'Çay öğütülmüş numunenin analize hazırlanması ve kuru madde tayini', Türk Standartları Enstitüsü, Necatibey Caddesi, No:112, Bakanlıklar, Ankara.

Anonim, 1990b. TS 1564, 'Çay toplam kül tayini', Türk Standartları Enstitüsü, Necatibey Caddesi, No:112, Bakanlıklar, Ankara.

Anonim, 2013. Meteoroloji İşleri Genel Müdürlüğü kayitlar1.

Anonymous, 1970. Official Methods of Analysis of the Association of Official Analytical Chemists. E.W. 
Horwitz. 11th Ed. 15.048 ( 2.051 ), Washington D.C.

Anonymous, 1982. Methods of Soil Analysis. Ed: A.L. PageNumber 9. Part:II. Madison, Wisconsin, USA.

Ateşalp, M., 1976. Aşırı kireçlemenin doğu Karadeniz Bölgesi asit topraklarının makro ve mikro besin maddeleri kapsamlarına ve verimlerine etkisi. Toprak ve Gübre araştırma Enstitüsü Müdürlüğü Yayınları, Genel Yayın No:72, Ankara.

Aydın, A., Sezen, Y., 1990. Kireçlemenin doğu karadeniz bölgesi asit topraklarının bazı özellikleri ile bazı makro ve mikro besin elementlerinin elverişliliğine etkisi. Atatürk Üniversitesi, Ziraat Fakültesi Dergisi, 21(1): 94-105.

Barik, K., Aydın, A., Kant Aydın, C., 2013. Leaching of different liming materials from acid soil and determination of liming period. Journal of Food, Agriculture\&Environment, 11(3-4): 863-866.

Chimdi, A., Gebrekidan, H., Kibret, K., Tadesse, T., 2012. Effects of liming on acidity-related chemical properties of soils of different land use systems in Western Oromia, Ethiopia. World Journal of Agricultural Sciences, 8(6): 560-567.

Dunn, L.E., 1943. Lime requirement determination of soils by means of titration curves. Soil Sci., 56:341351.

Eden, T., 1976. Tea thirt edition tropical agriculture series longman group limited, London.

Effa, E.B., Uwah, D.F., Iwo, G.A., Obok, E.E., Ukoha, G.O., 2012. Yield performance of popcorn (Zea mays L. everta) under lime and nitrogen fertilization on an acid soil. Journal of Agricultural Science, 4(10): 12-19.

Haynes, R.J., Ludecke, T.E., 1981. Effect of lime and phosphorus applications on concent rations of available nutrient sand on $\mathrm{P}, \mathrm{Al}$ and $\mathrm{Mn}$ uptake by two pasture legumes in an acid soil. Plant and Soil, 62: 117-128.

Kacar, B., 1984. Çayın gübrelenmesi, Çay İşletmeleri Genel Müdürlüğü, Çay-Kur Yayını No:4, Ankara, $\mathrm{s}: 356$.

Kacar, B., 2010. Çay Bitkisi. Biyokimyası. Gübrelenmesi. İşleme Teknolojisi. Nobel Yayın Dağıtım, 355 s., Ankara.

Kacar, B., Przemeck, E., Özgümüş, A., Turan, C., Katkat, A.V., Kayıkçığlu, İ., 1979. Türkiye'de çay tarımı yapılan toprakların ve çay bitkisinin mikroelement gereksinmeleri üzerinde bir araştırma. TÜBİTAK Tarım ve Ormancılık Araştırma Grubu. Proje No: TOAG-321, 67 s. Ankara.

Kacar, B., Taban, S., Kütük, A.C., 2004. Çay atıklarının zenginleştirilmiş organik gübreye dönüştürülmesi. 3 . Ulusal Gübre Kongresi, Tarım Sanayi Çevre Bildiri Kitab1, Cilt:1, Tokat, s. 805-814.

Kant, C., Barik, K., Aydın, A., 2006. Asidik topraklara uygulanan farklı kireçleme materyallerinin bazı toprak özellikleri ile mısır bitkisi (Zea mays L.)'nin gelişimi ve mineral içeriğine etkisi. Atatürk Üniversitesi Ziraat Fakültesi Dergisi, 37(2): 161167.
Kinez, M., 1964. Çay Ziraatı. Dizer Konca Matbaası, İstanbul.

Kovacevic, V., Rastija, M. 2010. Impacts of liming by dolomite on the maize and barley grain yields. Poljoprivreda, 16(2): 3-8.

Lindsay, W.L., Norvell, W.A., 1978. Development of a DTPA soil test for zinc, iron, manganese and copper. Soil Sci. Amer. Jour., 42(3): 421-428.

Martini, J.A., Mutter, R.G., 1985a. Effect of lime rates on nutrient availability, mobility and uptake during the soybean growing season: 1. Aluminum, manganese, and phosphorus. Soil Sci., 139: 219-226.

Martini, J.A., Mutters, R.G., 1985b. Effect of lime rates on nutrient availability, mobility and uptake during the soybear growing season: 2 Calcium, magnesium, potassium, iron, copper and zinc. Soil Sci., 139: 333343.

Müftüoğlu, M., Yüce, E., Turna, T., Kabaoğlu, A., Özer, S.P., Tanyel, G., 2010. Çay tarımı yapılan alanların bazı toprak ve bitki özelliklerinin değerlendirilmesi. Ege Üniversitesi Ziraat Fakültesi Dergisi Özel Sayı (5. Bitki Besleme ve Gübre Kongresi Bildirileri). İzmir.

Osundwa, M.A., Okalebo, J.R., Ngetich, W.K., Ochuodho, J.O., Othieno, C.O., Langat, B., Omenyo, V.S., 2013. Influence of agricultural lime on soil properties and Wheat (Triticum aestivum L.) yield and acidic soils of Uas in Gishu County, Kenya. American Journal of Experimentel Agriculture, 3(4): 806-823.

Öksüz, M., 1987. Ülkemizde seleksiyonla bulunan beş çeşit klon çayın bazı özellikleri ile bunlardan orthodoks ve rotorvane yöntemle elde edilen mamul çayların kalite karakteristiklerinin tespiti. Atatürk Üniversitesi Ziraat Fakültesi Dergisi, Cilt:18, say1:1-4, Erzurum.

Özen, N., Arat, E., 1999. Use of the first carbonification sludge of sugar in dustry as calcium source in quaildiets. Turk. J. Vet. Anim. Sci., 23(1): 35-40.

Özuygur, M., Ateşalp, M., Börekçi, M., 1974. Doğu Karadeniz topraklarının kireç ihtiyaçlarının tayininde uygulanacak metotlar ve kireçleme malzemeleri üzerine bir araştırma. TÜBİTAK Tarım ve Ormancılık Grubu Tübitak Yayınları No: 23. TOAG Seri No: 48, Ankara.

Özyazıcı, M.A., Dengiz, O., Aydoğan, M., 2013. Çay yetiştirilen tarım topraklarının reaksiyon değişimleri ve alansal dağılımları. Toprak Su Dergisi, 2(1): 2329.

Sağlam, M.T., 1978. Toprak kimyası tatbikat notları. Atatürk Üniversitesi Ziraat Fakültesi Toprak Bölümü, Erzurum.

Sarımehmet, M., Mahmutoğlu, H., 1991. Çayın gübrelenmesi ile ilgili bazı görüş ve öneriler. ÇayKur Dergisi, Y11:4, Say1:16.

Shamshuddin, J., Muhrizal, S., Fauziah, I., Husni, M.H.A., 2004. Effect of adding organic materials to an acid sulfate soil on the growth of cocoa (Theobrama cacao L.) seedlings. Science of The Total Environment, 323: 33-45. 
Sürücü, A., 1995. Asit toprakların kireç ihtiyaçlarının belirlenmesinde kullanılan farklı yöntemlerin karşılaştırılması üzerine bir araştırma. Yüksek lisans tezi, Ondokuz Mayıs Üniversitesi, Fen Bilimleri Enstitüsü, Samsun.

Şimşek, U., 1998. Asit topraklara uygulanan kirecin toprak özelliklerine, bitki gelişmesine ve besin elementi alımına etkisi ile yıkanma durumu. Yüksek lisans tezi, Atatürk Üniversitesi, Fen Bilimleri Enstitüsü, Erzurum.

Şinik, E., 2011. Edirne ilinde bulunan asit karakterli gübrelerin bitki besin elementleri ve bazı ağır metal içeriklerinin belirlenmesi. Yüksek lisans tezi, Trakya Üniversitesi, Fen Bilimleri Enstitüsü, Tekirdağ.

Taban, S., Okay, Y., Kunter, B., 2000. Değişik dönem ve dozlarda uygulanan yaprak gübresinin çay bitkisi yaprağının kalite ve mineral madde içerikleri üzerine etkisi. Tarım Bilimleri Dergisi, 6(1): 58-62.
Taban, S., Okay, Y., Kunter, B., 2001. Klon ve tohumdan üretilen çay bitkisinin genç ve yaşlı yapraklarının ekstrakt, polifenol, kül ve bazı mineral madde içerikleri. Glda Dergisi, 26(1): 49-53.

Tekeli, S.T. 1962. Çay teknolojisi. Ankara Üniversitesi Ziraat Fakültesi Yayınları 190, Ders Kitapları 64, Ankara Üniversitesi Basımevi, Ankara.

Ülgen, N., 1967. Şlam ile kireçleme araștırmaları. Toprak ve Gübre Araştırma Enstitüsü 1962-1963 Yılları Araştırma Raporu, Ankara.

Wijewardena, J.D.H., 2001. Effect of sources and levels of liming materials on soil acidity in Ulti sols of thecountry. Annals of The Sri Lanka Department of Agriculture, 3: 365-372.

Yursever, N., 1984. Deneysel İstatistik Metotlar1. Toprak ve Gübre Enstitüsü Yayınları, Genel Yayın No: 121, Ankara. 